\title{
THE ENLIGHTENMENT TO CHINA OF E-GOVERNMENT APPLICATION IN RURAL AREAS FROM JAPAN, SOUTH KOREA AND INDIA
}

\author{
Wenyun Liu ${ }^{1}$, Jinglei Wang ${ }^{1, *}$ \\ ${ }^{1}$ Institute of Scientific \& Technical Information, Shan Dong University of Technology, Zibo, \\ China, 255049 \\ * Corresponding author, Address: P.O. Box 342, Institute of Scientific \& Technical Information, \\ Shan Dong University of Technology, 12 Zhangzhou Road, Zibo, 255049, P. R. China, \\ Tel: +86-0533-2781428, Email: reeeee@126.com
}

Abstract: $\quad$ E-government is one of the major forms of government informatization. It has played an important role in the rural areas of some Asian countries. This article gives an analysis of e-government application in some rural areas in Asia and the status of e-government application in rural China, and gets some enlightenment to solve our problems.

Keywords: e-government, rural, enlightenment, Asia

\section{THE APPLICATION OF E-GOVERNMENT IN RURAL ASIA}

\subsection{Japan: Pays attention to agricultural information system. And its computer network develops rapidly}

First, Japan pays attention to the establishment of market rules and development policy on rural informationization. According to agricultural production and market operation rules, the government established a number of specialized advisory committee and formulated a series of system rules and operational rules to restrict the code of conduct of all aspects of the market. Moreover, the government established development policies 
according to the actual needs to promote the market operated orderly. Second, the government pays attention to agricultural infrastructure construction. Successive Japanese governments have attached great importance to rural telecommunication, broadcasting, and TV development. Currently, Japanese Ministry of Agriculture, Forestry and Fisheries are in the process of formulating a "21st Century Agriculture, Forestry and Fisheries fields of information strategy", and the basic idea is greatly augment the rural information and communication infrastructure, including the laying of fiber optic cable in order to build advanced communications network.

Japanese agricultural market information service is composed of two systems (Yang, 2005). One is the "Federation of Agricultural Central Market," the other is various agricultural products production volume and price forecasting system composed of the national 1800 "comprehensive agricultural group". With the accurate market information offered by the two systems, each farmer can know well of what is good market, the price, and each product's production quantity on the domestic market and even on the international market. They can identify and adjust their product and production according to their actual ability to make the production in a clear, highly orderly state.

Japan had developed more than 400 agricultural networks by the end of 1994. The computer prevalence rate had reached $93 \%$ in agricultural production sector. The agricultural and technological information network system developed in recently two years, farmers can query and use the network data at any time. Meanwhile, the Japanese government has attached great importance to the popularization and application of computers in rural areas, Japanese farmers will receive subsidies to purchase computer.

\subsection{South Korea: "information village" project}

The "information village" program started in 2001. The same year in March, the "information village planning groups" made up of the Ministry of Agriculture and Forestry and the Information and Communication Ministry, the Ministry and other government departments, administrative autonomy started planning and the experimental work, and was specifically responsible for the operation of the Ministry of administrative autonomy.

The ministry of administrative autonomy fixed on the first batch of more than 20 identified "information village" model as of May 2002, and gradually generalized when experience was gained. The project was welcomed by farmers quickly in the country and expanded rapidly. There were 78 and 88 "information model village" set up in central city in 2003 and 2004. There were newer 89 in 2005 . "Information model villages" were in a total of 280 and 79,300 farmers participated as of May 2005. 
Every "information model village" is a system engineering and essential construction project include: First, the construction of high-speed Internet infrastructure, including laying specific optical cable, constructing equipment installed mainframe room, achieving broadband Internet access to farmers; Second, it is necessary to establish rural information centers, and provide computer word processors and other hardware, and make the achievement of the information network connected with the local administration; Third, it establish farmers computer using environment, the existing model village has been able to equipped more than $73 \%$ of the rural households with computers; The fourth is to establish management operation system, the business committee is formed by the model village's villages, information-based instruction personnel and information center management personnel participate and run together. The fifth is the education and training of personnel. South Korea had trained 233,500 villagers to use computer and Internet, and cultivated a group of information technology and key management personnel in rural areas as of May 2004 (Cao, 2006).

The "information village" program has taken obvious effect. It behaved outstandingly that information network greatly facilitates the flow and transactions of produce and enliven the experience of rural tourism and cultivated the rural and native products brands. It made agriculture and rural areas got benefits and farmers' income increased. It contributed to increasing region's economic competitive promoted balanced regional development.

\subsection{India: GYANDOOR program and CSC program}

GYANDOOR program is a unique e-government project. As shown in Figure 1:

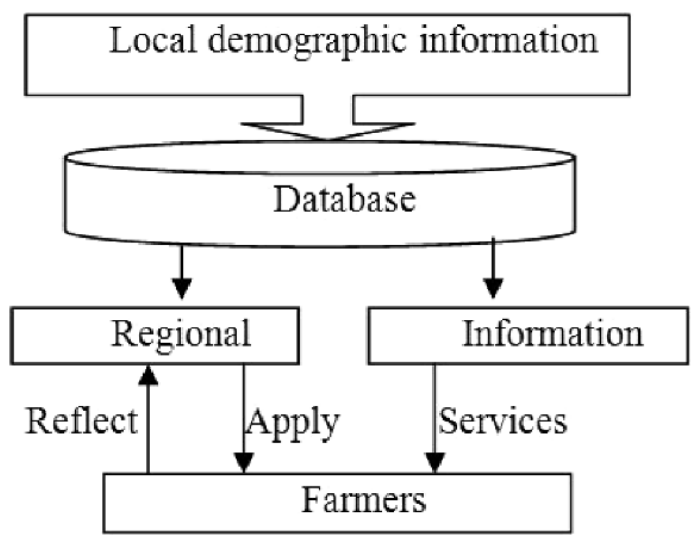

Figure 1. GYANDOOR program 
The project started in November 1999, mainly serviced rural areas and the tribal Dhar. A lot of important local demographic information such as income, estate, native place, ownership of land, creditor's rights are stored in computer. The network runs through regional capitals and 21 independent operate information centers. Most of these information centers locate in the town center street, which people often go across. There, each villager can enjoy a range of services such as a certificate of origin supply, housing ownership certificates, local welfare and the latest information on agricultural prices. Even if some farmers are illiteracy, they can also understand the price figures appeared on the screen with the operator's help.

In addition to the services above, the villagers could also reflect problems to the senior manager of the region through network, such as lack of agricultural experts, pump failure, official misconduct and dealers to sell fake seeds, inferior fertilizers and so on. There must be a reply in 7 days under the supervision. India is a big agricultural country, $70 \%$ of the population scattered in 600,000 villages, although the teledensity (fixed telecommunication and mobile communications) per capita share rate is only $7 \%$ in India, rural telecommunication services coverage rate reached $83 \%$. Moreover, they also set up a new target: any village within a radius of five kilometers can have the wireless Internet access.

Recently Indian cabinet approved the establishment of 100,000 broadband common service centers (CSC program). The aim is to popularize the digital services to every citizen, and increase the opportunities to the economic development of remote areas, and reduce the digital divide. Indian government also said that broadband common service center is one of the three major infrastructures of e-government. According to the program, the 100,000 broadband common service centers will distribute in rural areas reasonably to ensure that each center can service 6 villages. All the construction will be completed in 18 months.

This program will be carried out in cooperation of the government and the private sector. It is expected to cost 57.42 billion Indian rupees (about 1.254 billion U.S. dollars). Central government, regional governments and the private sector will offer the cost together. The private sector's participation is a positive force in Indian information technology program. Its existence will actively promote the process of information technology in the rural areas to work and behave in accordance with the rules of the market. It will be more flourish and durable. 


\section{THE STATUS OF E-GOVERNMENT APPLICATION IN RURAL CHINA}

\subsection{The deficiencies of e-government application in rural China}

The deficiencies of e-government application in rural China are shown in table 1.

Table 1. Deficiencies

\begin{tabular}{ll}
\hline Deficiencies & Details \\
\hline Low Internet popularity rate in rural & As shown in Figure 2, the 17th Chinese Internet \\
areas (CNNIC, 2006). & Development status Statistic shows that there is a \\
huge difference between urban and rural areas in \\
Internet popularity rate. It shows that the number of \\
Internet users in rural China is only one-fifth of \\
urban Internet users, and rural Internet popularity \\
rate is only one-sixth of urban Internet penetration \\
rate.
\end{tabular}

There is no uniform standard in website construction or inability to share information resources.

The agricultural websites are inadequate to farmers' needs (Fan, 2007).

Information form is single and not timely (Wang, 2006).
On one hand, the construction is low-level repetitive. On the other hand, there is no unified standard data. Valuable information resources belong to the agricultural sector, agricultural enterprises and related research institutions respectively even in the same agricultural information service website, and there is no cross between them.

Moreover, the content of the website is identical; its update speed is slow. Generally speaking, the financial investment in the agricultural gives more convenience than its benefits to farmers or agricultural enterprises. The information that reflects phenomenon is too much, but the information analyzed or assisting leaders to make macro decision and operators to make micro decision is too little.

Farmers' demand to information is various, for example, many agricultural crop farming skills need a large number of pictures and video to explain and demonstrate. But now, agricultural web pages are more static than dynamic and lack of website navigation, The site isn't vivid enough. It goes against farmers' learning and using. The sites can't update in time. The information on the website is incomplete and inaccurate, the content is dull and the value is low in use and practicality. 


\section{NOTES}

1. The following is the 17 th Chinese Internet Development status Statistic, as shown in Figure 2:

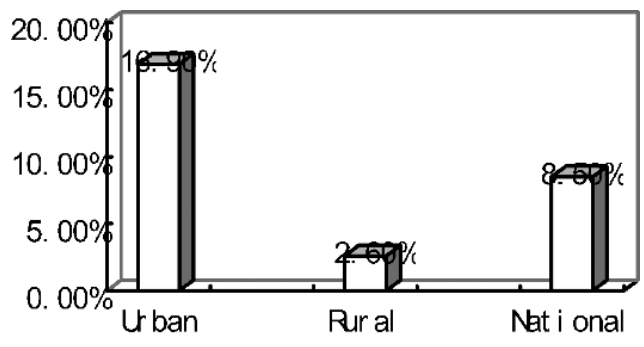

$\square$ Net i zen popul ar i ty rat e

Figure 2. The 17th Chinese Internet Development Status Statistic issued by CNNIC

\subsection{E-government achievements in rural China}

E-government achievements in rural China are shown in table 2. Table 2. Achievements

\begin{tabular}{ll}
\hline Achievements & Details \\
\hline Golden Agriculture Project (Liu, 2005). & $\begin{array}{l}\text { This project will further promote the } \\
\text { standardization of Chinese agricultural } \\
\text { construction. It can improve the government's } \\
\text { management and service levels }\end{array}$ \\
$\begin{array}{l}\text { We have built up an agricultural } \\
\text { information network system }\end{array}$ & $\begin{array}{l}\text { The Ministry of Agriculture has established a } \\
\text { national agricultural portal website with } \\
\text { Chinese agricultural information network as its } \\
\text { core including more than } 20 \text { professional } \\
\text { networks. We have built national agricultural } \\
\text { management satellite communications system } \\
\text { and national fishery command center, and } \\
\text { achieved national industry-wide command and } \\
\text { control network. }\end{array}$ \\
& $\begin{array}{l}\text { Agricultural departments at various levels actively } \\
\text { change their functions and responsibilities to fulfill } \\
\text { the government information service, make a } \\
\text { comprehensive exploration of information services, } \\
\text { and gradually become institutionalized. }\end{array}$ \\
The rural information service is &
\end{tabular}




\section{THE ENLIGHTENMENT TO CHINA}

We can get some enlightenment from the three counties above and we should take measures to solve our problems.

Table 3. Enlightenment \& Measures

\begin{tabular}{cl}
\hline No. & Enlightenment \& Measures \\
\hline 1 & $\begin{array}{l}\text { We must strengthen the building of rural infrastructure and improve the level of } \\
\text { information technology in the rural areas (Wang, 2006). } \\
\text { The government should provide analyzing and forecasting services and strengthen } \\
\text { the role of guidance. }\end{array}$ \\
3 & $\begin{array}{l}\text { We should strengthen the systemic training of farmers. We should improve } \\
\text { farmers' quality, and promote the effective use of information. }\end{array}$ \\
4 & We should formulate unified standards to strengthen rural information system. \\
5 & $\begin{array}{l}\text { We should adopt various methods to disseminate information to farmers according } \\
\text { to local conditions. }\end{array}$ \\
6 & $\begin{array}{l}\text { We should create the information needs of farmers, and strengthen the farmers' } \\
\text { sense of information. } \\
7\end{array}$
\end{tabular}

We conceive an agricultural information system, as shown in Figure 3:

The core of the system is local agricultural Information center. It is responsible for carrying transferring and controlling messages; Portal is

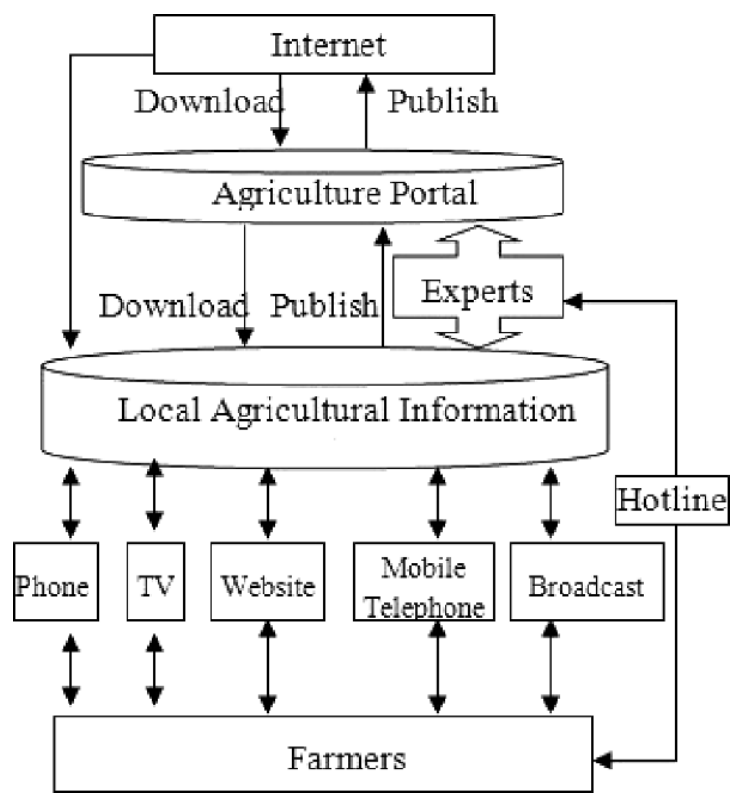

Figure 3. Agricultural Information system 
responsible for information collection, processing and dissemination. Experts are responsible for the technical support, the provision of information and management. Farmers can obtain the useful information from TV, website, Mobile telephone, Broadcast and hotline.

This system has the following advantages:

(1) It is easy for farmers to obtain the information; they can obtain the information in many ways, such as TV, website, Mobile telephone, Broadcast and hotline.

(2) Farmers can obtain the information immediately. They can obtain the information through SMS platform by mobile telephone.

(3) Farmers can obtain authoritative information form the experts; the information they obtained is very professional.

(4) The system is very integrated. Portal, information centers, experts, a fixed telephone, television, websites, mobile phones and radio form an integrated information system in rural areas. It overcomes the problem that farmers don't have computer, they can obtain information by phone or TV etc.

May this system play an important role in rural informatization.

\section{REFERENCES}

Cao Shigong, Korea: "Information village project”, Economic Daily, 2006-05-23

Fan Jizheng; Yang Jinzhong, Reasons and solutions for low pertinence of agriculture websites user groups, Agriculture Network Information, 2007, (2):71-73

Liu Shihong, On the Strategic Task of the Sustainable Development of Rural IT Application in China, Journal of Library and Information Sciences In Agriculture, 2005, (2):5-9

Liu Wenyun, On Chinese e-government framework. Journal of Shandong University of Technology, 2003, (5):35-38

Report on the development of Chinese Internet, CNNIC, 2006, (1)

The way Indian popularize information technology in the rural areas is worth learning, http://www.ciia.org.cn/genfiles/1163477046.html, 2006-11-14

Wang Xiangdong, The enlightenment and compare of different e-government, Informatization Construction, 2006, (5):13-17

Wang Yan, Chen Liang, Research on the Present Developing Situation of Chinese Rural Informatization and Its Construction Thought, Sci-Tech Information Development \& Economy, 2007, (12):146-148

Wang Yukai, Chinese e-government development prospects, Informatization Construction, 2006, (1):10-15

Yang Yi, A Brief View on the Development of Japanese IT Agriculture and the Enlightenment for China, Contemporary Economy In Japan, 2005, (6):60-62 